\title{
Standardization of Herbal Tea Quality Production Baureno Bojonegoro Society
}

\author{
Pirim Setiarso \\ Department of Chemistry \\ Universitas Negeri Surabaya \\ Surabaya, Indonesia \\ pirimsetiarso@unesa.ac.id
}

\author{
Rusijono \\ Department Education Technology \\ Universitas Negeri Surabaya \\ Surabaya, Indonesia \\ rusijono@unesa.ac.id
}

\author{
Asrul Bahar \\ Department of Family Welfare \\ Education \\ Universitas Negeri Surabaya \\ Surabaya, Indonesia \\ asrulbahar@unesa.ac.id
}

\author{
Samik \\ Department of Chemistry \\ Universitas Negeri Surabaya \\ Surabaya, Indonesia \\ samik@unesa.ac.id
}

\author{
Nita Kusumawati \\ Department of Chemistry \\ Universitas Negeri Surabaya \\ Surabaya, Indonesia \\ samik@unesa.ac.id
}

\begin{abstract}
Standardization of ginger and curcuma tea produced by the Baureno Bojonegoro society was carried out. To get high quality products, standardization has been carried out by the washing, slicing and drying processes. Washing ginger and curcuma rhizomes was carried out for $1 \mathrm{~min}$, with a thickness of $0.15 \mathrm{~cm}$ on each slice. To increase the shelf life of the product, it is dried on oven at $100{ }^{\circ} \mathrm{C}$. Standardization results show optimal quality with water content of $10.83 \%$, essential oil content of $4.01 \%$, oleoresin of $1.53 \%$, zingiberene (essential oil) $84.88 \%$, gingerol (oleoresin) $67.42 \%$, and shogaol in oleoresin of $33.95 \%$. Meanwhile, curcuma tea products have a water content of $8.20 \%$ with essential oil content of $2.05 \%$, curcuminoid of $1.09 \%$, xantorizol in essential oils of $65.17 \%$, and curcumin in curcuminoids of $85.50 \%$. Furthermore, the processing of ginger and curcuma commodities cultivated by the Baureno Bojonegoro society has succeeded in increasing the shelf life from during 29 days to 148 days for ginger tea products, and from during 22 days to 145 days for Curcuma tea products.
\end{abstract}

Keywords—tea; ginger; curcuma; washing; slicing; drying

\section{INTRODUCTION}

Indonesia is an agricultural country that has around 30,000 types of herbal plants. Some types of herbal plants in Indonesia have been recognized by the World Health Organization (WHO) because of their proven efficacy [1]. Some examples of Indonesian herbal plants that have proven efficacy are ginger (Zingiber officinale Roscoe) and Curcuma (Curcuma xanthorrhiza). Ginger contains shogaols, zingerone, and gingerols. The compounds contained in ginger have been proven to be able to overcome colds, flu and menstrual pain [2]. Meanwhile, curcuma contains curcumin, demethoxycurcumin and bisdemethoxycurcumin compounds. These three compounds have been shown to have anti-oxidant, anti-bacterial, anti-carcinogenic and antiinflammatory properties [3].

Rhizome plants such as fresh ginger and curcuma contain a fairly high water content, which is around $85-95 \%$. The high water content in fresh ginger and curcuma rhizomes makes the plant have a low shelf life because it is susceptible to decay by microbes. One effort to increase the shelf life of rhizome products is by drying. Drying traditionally using sunlight is still the main choice especially in developing countries [2]. However, drying using sunlight has many negative effects such as contaminants caused by fungi, insects and microbes. Besides drying is traditionally very dependent on the weather which makes it inefficient [3]-[4].

To improve the quality of herbal teas produced by the Baureno Bojonegoro society, drying is carried out using an oven. Nevertheless, it is important to carry out temperature control. Application of too high temperature will cause the loss of active ingredients of the tea. Drying with the right temperature will not only be able to maintain active compounds, but will also produce tea products with minimum water content, so that the shelf life can be increased [5][10][11]. Thus, the economic potential of the herbs commodities cultivated by the Baureno Bojonegoro society can be increased. To get uniform quality of tea products, standardization of the ginger and curcuma tea is carried out with reference to SNI 01-3393-1994.

\section{MATERIAL AND METHODS}

\section{A. Materials}

The main ingredients used are ginger (Zingiber officinale R.) and curcuma (Curcuma xanthorrhiza) which are both obtained from the harvest of Baureno Bojonegoro society. Meanwhile, to get standardized ginger and curcuma tea products, a number of tools are used, namely: (1) washing machine (self made); (2) slicing machine (capacity $60 \mathrm{~g} / \mathrm{min}$ with $0.15 \mathrm{~cm}$ sliced thickness); and (3) drying machine (temperature range $50^{\circ} \mathrm{C}-250^{\circ} \mathrm{C}$ ).

\section{B. Methods}

The herbal tea making process carried out by the Baureno Bojonegoro society includes drying, washing, and sclicing. Tea production begins with the process of washing fresh rhizomes for 1 minute. After washing, the rhizomes are dried 
for $24 \mathrm{~h}$ at room temperature. The dried rhizome is then sliced with a thickness of $0.15 \mathrm{~cm}$. Rhizome slices then dried.

Drying the rhizome in this stage is done with an oven at $100^{\circ} \mathrm{C}$. The drying process is carried out with a sample reversal every $30 \mathrm{~min}$, until a constant weight is obtained. These two grams of dried tea are then put into a tea bag and then packed by the Baureno Bojonegoro society.

\section{RESULT AND DISCUSSION}

Washing, slicing and drying standardization in the production of herbal teas done to improve the quality of herbal teas produced by the Baureno Bojonegoro society. Tea quality is evaluated based on water content and active compounds. Table I shows the water content, while table II shows the magnitude of the active compound of herbal tea produced by washing for 1 minute, the thickness of the material is $0.15 \mathrm{~cm}$ and drying with a temperature of $100{ }^{\circ} \mathrm{C}$.

TABLE I.

DRYING TIME AND WATER CONTENT OF GINGER AND CURCUMA TEA RESULTED FROM WASHING TIME STANDARIZATION

\begin{tabular}{|c|l|c|c|}
\hline No & Simplicia's Type & $\begin{array}{c}\text { Drying } \\
\text { Time } \\
(\mathbf{m i n})\end{array}$ & $\begin{array}{c}\text { Water } \\
\text { Content } \\
(\boldsymbol{\%})\end{array}$ \\
\hline 1 & Ginger & 410 & 10.83 \\
\hline 2 & Curcuma & 390 & 8.20 \\
\hline
\end{tabular}

Note

1. Thickness of material $0,15 \mathrm{~cm}$

2. Drying temperature $100{ }^{\circ} \mathrm{C}$

3. Dryer dimension : $15 \mathrm{~cm} \times 6.5 \mathrm{~cm} \times 4 \mathrm{~cm}$

4. Tea's weight : 60 grams

Based on the data in table $\mathrm{I}$, it is known that the application of $1 \mathrm{~min}$ washing time, $0.15 \mathrm{~cm}$ slice thickness and oven drying using a temperature of $100{ }^{\circ} \mathrm{C}$ in the production of ginger and curcuma tea has produced a final water content that meets the water content requirements set by Materia Medika Indonesia, which is a maximum of $12 \%$ [4]. The application of longer washing times tends to provide longer opportunities for water adsorption into ginger and curcuma raw materials, which in turn will lead to longer drying times and the acquisition of ginger and curcuma tea products with higher water content. Furthermore, to determine the potential use of ginger and curcuma tea products produced by the Baureno Bojonegoro society, an analysis of the active compound content was carried out. In Fig. 1, the ginger tea production process is seen, while in Fig. 2 the curcuma tea production is shown.
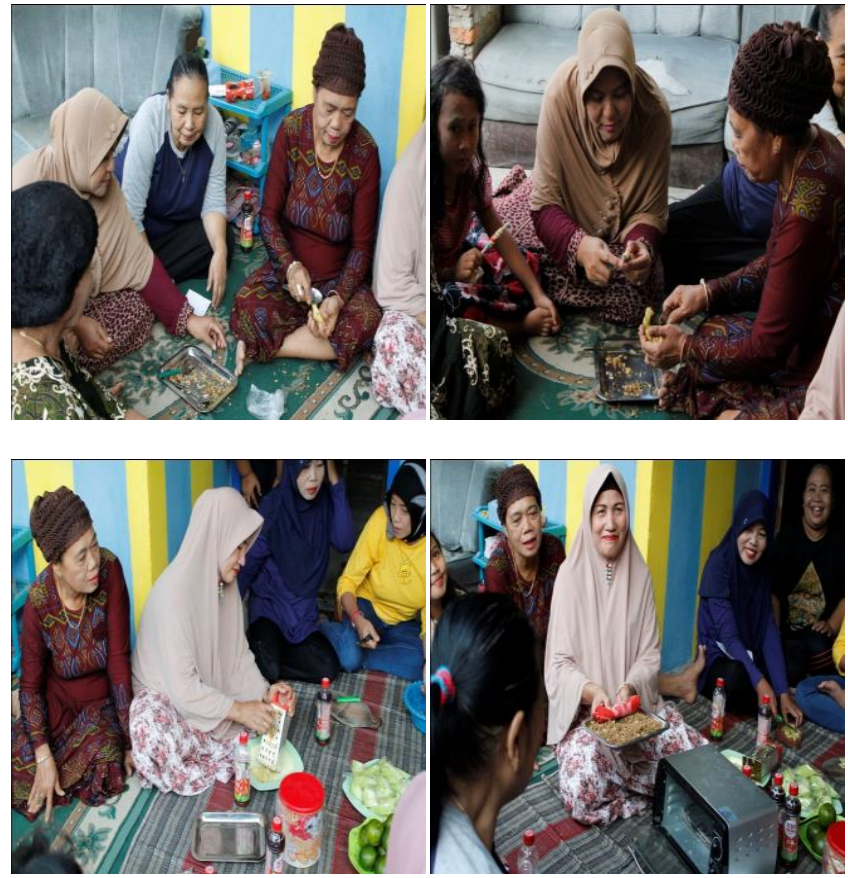

Fig. 1. The production process of ginger tea by Baureno Bojonegoro society
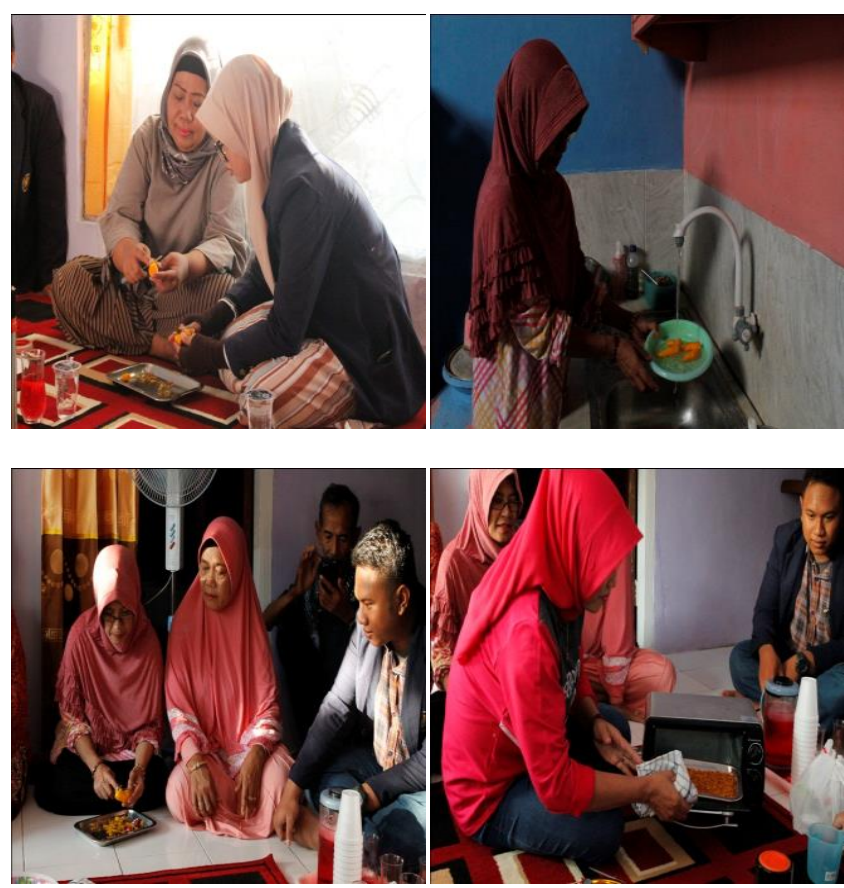

Fig. 2. The production process of curcuma tea by Baureno Bojonegoro society

The application of improper washing time, too long or too short, will affect the water and active compounds content of herbal tea products. Washing raw materials that are too short will leave a large number of contaminants in rhizome raw materials, which in turn will cause ginger tea products produced by the Baureno Bojonegoro society to be 
unable to meet the quality standards set by Materia Med Indonesia [4]. Meanwhile, washing time that is too long will facilitate the solubility of a number of active compounds, which in turn will reduce the benefits of ginger tea products.

In the washing procedure that is too long will have the most significant impact on the content of shogaol in ginger tea and curcumin in curcuma tea products. The content of zingiberene which is higher than the content of gingerol and shogaol is caused by the zingiberene structure which has hydrogen and carbon atoms which creates hydrophobic characteristics, thus inhibiting the solubility of these compounds in polar solvents such as water, the structure of gingerol and shogaol has a polar group in the form of $-\mathrm{OH}$ wherein the functional group increases polarity. Increasing the polarity of both automatically increases solubility in polar solvents such as water. When compared with shogaol, the solubility of gingerol in water is higher because gingerol has a more polar molecular structure. In line with this, The more polar functional groups in curcumin has triggered a greater impact from the application of too long washing time, namely in the form of a decrease in the curcumin content in curcuminoids in curcuma tea products. Fig. 3 show some molecular structure of compounds contained in herbal teas (zingiberene, gingerol and shogaol) while in Fig. 4 the molecular structure of xanthorizol and curcumin contained in curcuma tea products.

TABLE II.

CTIVE COMPOUND CONTENT OF GINGER AND CURCUMA TEA RESULTED FROM WASHING TIME STANDARDIZATION

\begin{tabular}{|c|c|c|c|c|c|c|}
\hline \multirow[b]{2}{*}{ 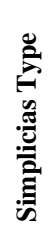 } & \multirow{2}{*}{ 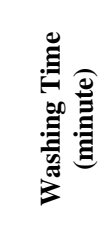 } & \multicolumn{5}{|c|}{ Active Compound Content (\%) } \\
\hline & & 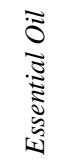 & 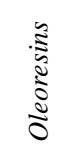 & 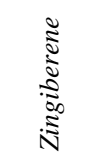 & $\begin{array}{l}\overline{0} \\
\bar{v} \\
\stackrel{0}{0} \\
\tilde{0}\end{array}$ & $\begin{array}{l}\tilde{8} \\
\text { \& } \\
\text { के }\end{array}$ \\
\hline 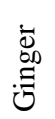 & 1 & 4.01 & 1.53 & 84.88 & 67.42 & 33.95 \\
\hline \multirow[b]{2}{*}{ 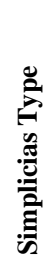 } & \multirow[b]{2}{*}{ 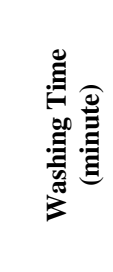 } & \multicolumn{5}{|c|}{ Active Compound Content (\%) } \\
\hline & & 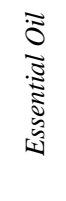 & 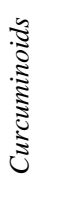 & 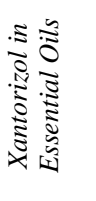 & \multicolumn{2}{|c|}{ 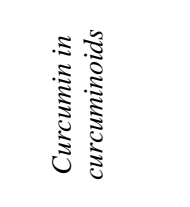 } \\
\hline 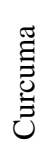 & 1 & 2.05 & 1.09 & 65.17 & \multicolumn{2}{|c|}{85.50} \\
\hline
\end{tabular}

The slices thickness standardization of the raw material in the production of herbal tea made by the Baureno Bojonegoro society is an equally important stage. To get herbal tea products with a longer shelf life, rhizome slices should not be too thick. As can be seen in Table I, it is known that the standardized thickness of slices in the production of herbal tea has a water content that meets the standards set by Materia Medika Indonesia [4]. High thickness at the rhizome will trigger the need for higher drying temperature to evaporate water to a certain depth of rhizome. However, it should be noted that the application of too high drying temperature will pose a risk of face hardening during drying. Face hardening is an event where the evaporation of water with high temperatures has caused hardening on the surface of the material, thereby inhibiting the evaporation of water in the layers inside. This condition will cause the acquisition of drying products with higher water content. Vice versa, the production of herbal tea with the slices thickness of the rhizome that is too low is predicted to trigger a significant decrease in the active compound content of the ginger and curcuma rhizome, especially in higher temperature. In Fig. 5, rhizomes with 0.15 thickness were produced by the Baureno Bojonegoro society.<smiles>CC(C)=CCCC(C)C1C=CC(C)=CC1</smiles>

(a)<smiles>CCCCC[C@H](O)CC(=O)CCc1ccc(O)c(OC)c1</smiles>

(b)<smiles>CCCCC/C=C/C(=O)CCc1ccc(O)c(OC)c1</smiles>

(c)

Fig. 3. Molecular structure of: (a) zingiberene; (b) gingerol; and (c) shogaol in ginger tea product<smiles>CC(C)=CCCC(C)c1cccc(O)c1</smiles>

(a) 
<smiles>COc1cc(/C=C/C(=O)CC(=O)/C=C/c2ccc(O)c(OC)c2)ccc1O</smiles>

(b)

Fig. 4. Molecular structure of: (a) xanthorizol; dan (b) curcumin in curcuma tea product
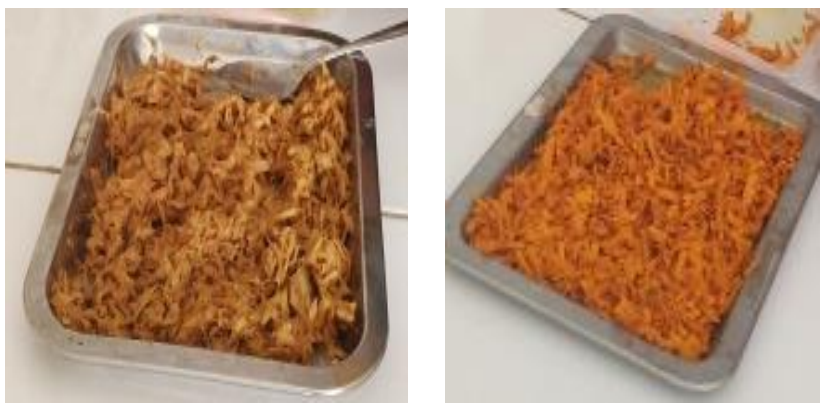

Fig. 5. Rhizome slices: (a) ginger; and (b) curcuma with a thickness of $0.15 \mathrm{~cm}$

In addition to washing time and sliced thickness of rhizome raw materials, drying time also plays an important role in the production of ginger and curcuma tea. Fig. 6 shows the ginger and curcuma rhizomes that have been dried by the Baureno Bojonegoro society. The process of rhizome raw materials drying using temperatures that are too low is predicted to extend the required drying time, even though rhizome raw materials in wet conditions have limited durability. This condition will cause rhizome decay before drying is complete. Conversely, the drying temperature that are too high will actually cause a face hardening event that results in herbal products with higher water content than ideal conditions.

TABLE III.

SELF LIFE OF GINGER AND CURCUMA TEA BEFORE AFTER STANDARDIZATION

\begin{tabular}{|c|c|c|c|}
\hline No & $\begin{array}{c}\text { Simplicia' } \\
\text { s Type }\end{array}$ & $\begin{array}{c}\text { Self life before } \\
\text { drying } \\
\text { standardization } \\
\text { (days) }\end{array}$ & $\begin{array}{c}\text { Self life after } \\
\text { drying } \\
\text { standardization } \\
\text { (days) }\end{array}$ \\
\hline 1 & Ginger & 29 & 148 \\
\hline 2 & Curcuma & 22 & 145 \\
\hline
\end{tabular}

In general, production stages standardization of herbal tea production by Baureno Bojonegoro society has produced herbal products with low water content, which meet the Indonesian Materia Medika standards of quality herbal products. This condition is expected to be able to extend the shelf life of the two herbal products produced by this society. To evaluate the effect of herbal production standardization on the shelf life of the product concerned, an analysis of the shelf life of ginger and curcuma tea products produced by the Baureno Bojonegoro society, using the critical water content approach [9] and the results are shown in Table III. These results indicate that the production of ginger with standard operational conditions has increased the shelf life of the ginger rhizome from 29 days to 148 days. In line with this, the application of the same procedure has increased the shelf life of fresh curcuma commodities from 22 days to 145 days. In Fig. 7, ginger and curcuma tea products produced by Baureno Bojonegoro society with standardized operational conditions.

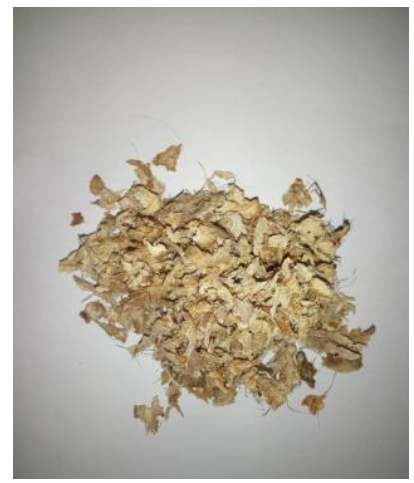

(a)

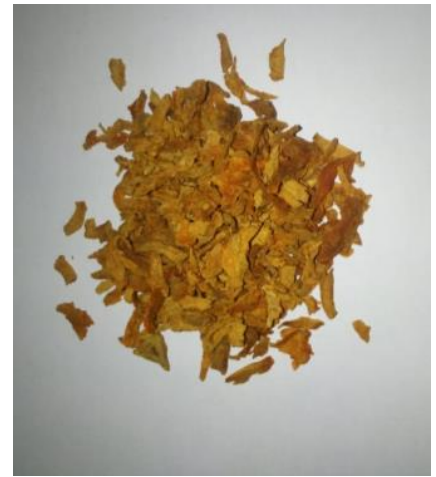

(b)
Fig. 6. Dried rhizome of: (a) ginger; and (b) curcuma produced by Baureno Bojonegoro society

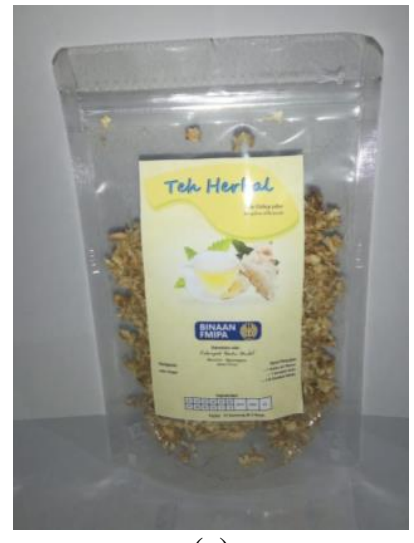

(a)

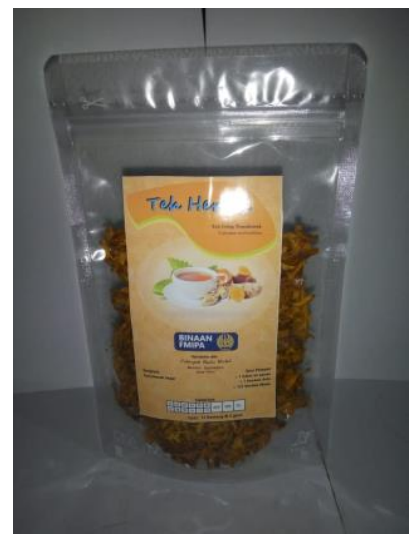

(b)
Fig. 7. Ginger (a); and (b) curcuma tea product produced by Baureno Bojonegoro society

\section{CONCLUSION}

Standardization of herbal tea production by the Baureno Bojonegoro society has been carried out. The standardization includes washing duration, slice thickness, and drying temperature. To get the quality of herbal products produced, water content and product active compounds have been evaluated. The results of standardization showed that with a washing time of 1 minute, the thickness of the slices was $0.15 \mathrm{~cm}$, and the drying temperature of $100{ }^{\circ} \mathrm{C}$ had optimum quality.The water content in tea products is $10.83 \%$ with an essential oil content of $4.01 \%$; oleoresin of $1.53 \%$; zingiberene in essential oils of $84.88 \%$; gingerol in oleoresin of $67.42 \%$; and shogaol in oleoresin of $33.95 \%$. Meanwhile, temulawak tea products have a water content of $8.20 \%$ with essential oil content of $2.05 \%$, curcuminoid of $1.09 \%$; xantorizol in essential Oils of $65.17 \%$; and curcumin in curcuminoids of $85.50 \%$. Furthermore, the processing of 
ginger and curcuma commodities cultivated by Baureno Bojonegoro society has succeeded in increasing the shelf life from during 29 days to 148 days for ginger tea products, and from during 22 days to 145 days for Curcuma tea products.

\section{ACKNOWLEDGMENT}

Thank you to the Ministry of Research and Technology, Higher Education of the Republic of Indonesia for providing financial support through the Community Partnership Program.

\section{REFERENCES}

[1] Departemen Kesehatan Republik Indonesia, "Pemanfaatan Tanaman Obat", 2013

[2] J. Wang, T. Y. Bai, D. Wang, X. M. Fang, L. Y. Xue, Z. A. Zheng, Z. J. Gao and H. W. Xiao, "Pulsed vacuum drying of Chinese ginger (Zingiber officinale Roscoe) slices: Effects on drying characteristics, rehydration ratio, water holding capacity, and microstructure", Drying Technology, 2018.

[3] S. Hadi, A. N. Artanti, Y. Rinanto, D. S. C. Wahyuni, "Curcuminoid content of Curcuma longa L. and Curcuma xanthorrhiza rhizome based on drying method with NMR and HPLC-UVD”, IOP Conf. Series: Materials Science and Engineering, 349, 2018.

[4] Kesehatan Republik Indonesia, "Materia Medika Indonesia", Jilid III, Departemen Kesehatan Republik Indonesia, 1979.

[5] I. Doymaz, Convective drying kinetics of strawberry. Chemical Engineering and Processing, 47, pp. 914-919, 2008.
[6] N. Kusumawati, M. A. Anggarani, Rusijono, P. Setiarso, S. Muslim1, "Product Standarization of Ginger (Zingiber officinale Rosc.) and Red Ginger (Zingiber officinale var. Rubrum) Simplicia through Washing Time, Slice Thickness and Raw Materials Drying Process Optimization", international Journal on Advanced Science Engineering Information Technology, vol 7(1), 2017.

[7] M.L. Barek, M. Hasmadi, A.Z. Zaleha, and A.B.Mohd Fadzelly, "Effect of different drying methods on phytochemicals and antioxidant properties of unfermented and fermented teas from Sabah Snake Grass (Clinacanthus nutans Lind.) leaves", International Food Research Journal, vol. 22(2), pp. 661-670, 2015.

[8] B.S. Sembiring, S. Yuliani, "Penanganan dan pengolahan rimpang jahe," Balai Besar Penelitian dan Pengembangan Pascapanen Pertanian, Status Teknologi Hasil Penelitian Jahe, 2011.

[9] F. Kusnandar, D. R. Adawiyah, M. Fitria, "Pendugaan umur simpan produk biskuit dengan metode akselerasi berdasarkan pendekatan kadar air kritis, Jurnal Teknologi dan Industri Pangan, 21 (2), 2010.

[10] P. Setiarso, N. Kusumawati, Rusijono and S. Muslim, "Optimization of slice thickness, drying method, and temperature of turmeric rhizome (curcuma longa 1.) Based on water content and functional compound degradation", Atlantis Highlights in Engineering, 1, 2018.

[11] P. Setiarso, Rusijono, Samik and N. Kusumawati, "The production and characterization of kaempferia galanga 1. -based herb powder: blanching and drying procedure influence on proximate, metal, and microbial contamination", Advances in Engineering Research, 171,2018 